\title{
Perawatan Maloklusi Klas III dengan Reverse Overjet Menggunakan Alat Ortodontik Cekat Teknik Begg
}

\author{
Yohana Retno Wikandari Purwaningsih*, Wayan Ardhana**, dan Christnawati** \\ *Program Studi Ortodonsia PPDGS Fakultas Kedokteran Gigi Universitas Gadjah Mada \\ **Bagian Ortodonsia Fakultas Kedokteran Gigi Universitas Gadjah Mada \\ *Jl Denta no 1 Sekip Utara Yogyakarta, retno.wikandari@yahoo.com
}

\begin{abstract}
ABSTRAK
Maloklusi klas III true skeletal merupakan kasus yang sulit dirawat dan mudah terjadi relaps. Perawatan ideal kasus ini memerlukan tindakan bedah, namun apabila hal tersebut tidak memungkinkan maka dilakukan perawatan kamuflase. Reverse overjet, atau gigitan terbalik, tipikal mempunyai penyimpangan posisi insisivus atas dan bawah akibat malrelasi maksila dan atau mandibula. Tujuan artikel ini adalah menyajikan perawatan ortodontik kamuflase menggunakan teknik Begg pada maloklusi ini. Pasien perempuan umur 24 tahun mengeluhkan gigi depan berjejal dan tidak nyaman untuk mengunyah makanan. Diagnosis kasus adalah maloklusi Angle klas III, hubungan skeletal klas III dengan protrusif bimaksilar, incisivus atas dan bawah retrusif, pergeseran median line rahang atas ke kanan, disertai edge to edge bite anterior, cross bite posterior dan openbite posterior. Pasien dirawat dengan pencabutan gigi premolar kedua atas,dan premolar pertama bawah untuk mengatasi kondisi kasus tersebut. Kesimpulan dua tahun setelah perawatan, tampak sudut interinsisal berkurang, reverse overjet terkoreksi, edge to edge bite, cross bite dan openbite terkoreksi.
\end{abstract}

Maj Ked Gi. Juni 2013; 20(1): 112 - 118

Kata kunci : maloklusi klas III, reverse overjet, teknik Begg, kamuflase

\begin{abstract}
Treatment of Class III malocclusion with Reverse Overjet using Orthodontic Begg Technique. A true skeletal class III malocclusion is a difficult case to be treated as it can get easily relap. The ideal treatment of this skeletal types requires a surgery, but if it is not possible, an orthodontic camouflage can be conducted. Reverse overjet typically has upper and lower incisor position deviation due to the mesial position of the mandible in relation to the maxilla. The purpose of this article is to present camouflage orthodontic treatment using Begg orthodontic technique in Class III malocclusion case with reverse overjet. A 24 year-old female patient complained about her front teeth crowding and uncomfortable mastication. From the diagnosis, there was true dento skeletal class III malocclusion with bimaxilary protrusion, bidental retrusion and edge to edge bite. The lower incisors were shifted to the right. The posterior teeth were crossbite and openbite. The patient were treated with extraction of the right upper second premolars and lower first premolars. After 2 years of treatment, it is concluded that the interinsisal angle decreases and the reverse overjet, the edge to edge bite, the crossbite and the openbite are corrected as well.

Maj Ked Gi. Juni 2013; 20(1): 112 - 118
\end{abstract}

Keywords: true skeletal Class III malocclusion, reverse overjet, Begg technique, camouflage

\section{PENDAHULUAN}

Maloklusi yang disebabkan oleh disharmoni skeletal sering kali mengakibatkan disharmoni wajah, keadaan tersebut akan mempengaruhi estetika, menimbulkan masalah pengunyahan dan bicara. Maloklusi klas III atau prognatisme, adalah hubungan tonjol mesiobukal gigi molar pertama rahang atas terletak sebelah posterior cekung mesio bukal gigi molar pertama rahang bawah. Gigi anterior rahang bawah lebih maju terhadap rahang atas. Maloklusi klas III dengan reverse overjet (gigitan terbalik) dapat disebabkan oleh kondisi rahang atas kecil dan rahang bawah normal, atau rahang atas normal dengan rahang bawah besar. Koordinasi yang kurang antara ukuran rahang atas dengan rahang bawah dapat juga mengakibatkan bukal crossbite baik unilateral maupun bilateral. Sudut gonial pada maloklusi klas III bervariasi dari tinggi ke rendah yang berhubungan dengan meningkatnya atau berkurangnya tinggi wajah maupun overbite. Lengkung gigi rahang bawah bervariasi dari rata-rata sampai di atas rata-rata, sedangkan variasi lengkung 
gigi rahang atas dari pendek ke panjang, yang berhubungan dengan terjadinya gigi berjejal pada rahang atas atau sebaliknya., ${ }^{1,3}$

Tingkat keparahan maloklusi klas III mempengaruhi rencana perawatan dan prog-nosis perawatan ortodontik. Maloklusi klas III yang disebabkan oleh malrelasi rahang atas dan rahang bawah dengan kelainan skeletal ringan maka perawatan ortodontik tidak terlalu sulit. Keterlibatan faktor skeletal secara klinis dapat diketahui melalui menggerakkan rahang bawah menuju posisi gigi insisivus kontak secara normal. Beberapa pasien berhasil menggerakkan rahang bawah mendekati posisi insisivus normal maupun edge to edge, dan sebagian tidak dapat melakukan hal tersebut. Kondisi maloklusi klas III yang parah tidak dapat dirawat hanya melalui perawatan ortodontik saja, tetapi memerlukan tindakan pembedahan. Pasien yang tidak mampu secara ekonomi hanya melakukan perawatan maloklusi pada gigi saja tanpa menjalani pembedahan. Salah satu teknik perawatan maloklusi pada kasus tersebut dilakukan dengan teknik Begg. 4,5,6,7

Teknik Begg merupakan salah satu teknik perawatan ortodontik cekat dengan gaya yang ringan, bergerak bebas tanpa friksi. Kawat yang digunakan berbentuk bulat dan bracket ribbon arch. Gerakan yang dihasilkan oleh alat ini adalah tipping mahkota gigi secara bebas. Perawatan dengan teknik Begg dilakukan melalui 3 tahap, tahap pertama merupakan tahap leveling dan unreavelling. Tahap kedua penutupan ruang bekas pencabutan, dan tahap ketiga merupakan tahap finishing dan root paralleling. Komponen yang digunakan tergantung pada tujuan yang akan dicapai. ${ }^{8.9}$ Artikel ini bertujuan memaparkan perawatan maloklusi klas III dengan reverse overjet menggunakan alat ortodontik cekat teknik Begg.

\section{STUDI KASUS}

Pasien perempuan berumur 24 tahun datang ke klinik Ortodonsia RSGM Prof. Soedomo, FKG UGM Yogyakarta dengan keluhan gigi anterior berjejal dan tidak nyaman untuk mengunyah makanan (gambar 1, 2, 3, dan 4). Hasil pemeriksaan intra oral menunjukkan $\mathrm{OHI}$ baik, ukuran lidah sedang, lebar dan tinggi palatum sedang. Lengkung gigi atas berbentuk trapezium asimetris, rahang bawah parabola simetris. Hubungan gigi molar pertama klas III Angle, hubungan gigi kaninus kanan klas III Angle sedangkan hubungan kaninus kiri klas I Angle. Terdapat malrelasi reverse overjet $3 \mathrm{~mm}$ dan overbite 3,1 $\mathrm{mm}$, edge to edge bite anterior, cross bite posterior, serta open bite posterior. Median line rahang atas bergeser ke kanan $1 \mathrm{~mm}$. Berdasarkan Analisis sefalometri disimpulkan bahwa pasien memiliki hubungan skeletal klas III dengan protrusif bimaksilar, gigi insisivus rahang atas dan bawah retrusif. Dagu tidak dapat mengayun pada posisi edge to edge, sehingga disimpulkan kelainan yang terjadi adalah klas III true skeletal. FIS (FrankfortIncisive Superior) awal $100^{\circ}$, sudut interinsisal awal $158^{\circ}$ dan IMPA (Incisor Mandibular Plane Angle) awal $81,5^{\circ}$ (Tabel 1). Diagnosis kasus ini adalah maloklusi Angle Klas III, hubungan skeletal klas III dengan protrusif bimaksilar, gigi insisivus rahang atas dan bawah retrusif serta pergeseran median line rahang atas ke kanan.

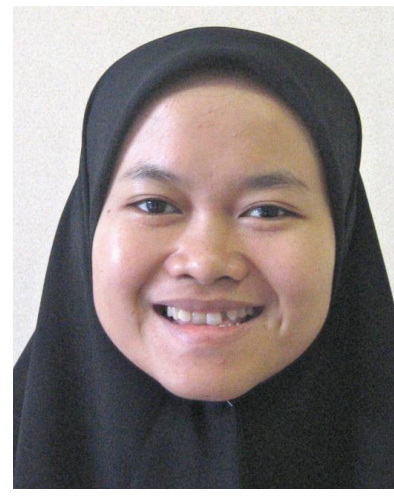

(A)

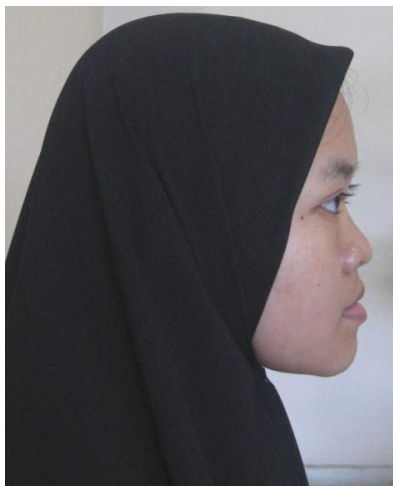

(B)
Gambar 1. (A)Tampak depan sebelum perawatan. (B) Profil samping sebelum perawatan

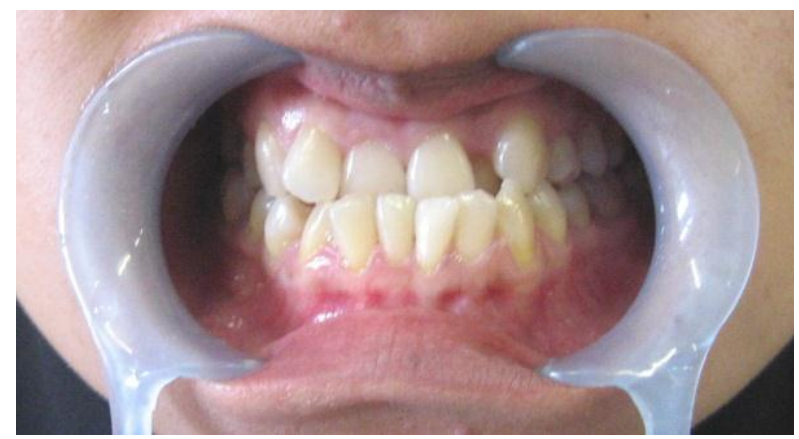

Gambar 2. Tampak depan sebelum perawatan. 


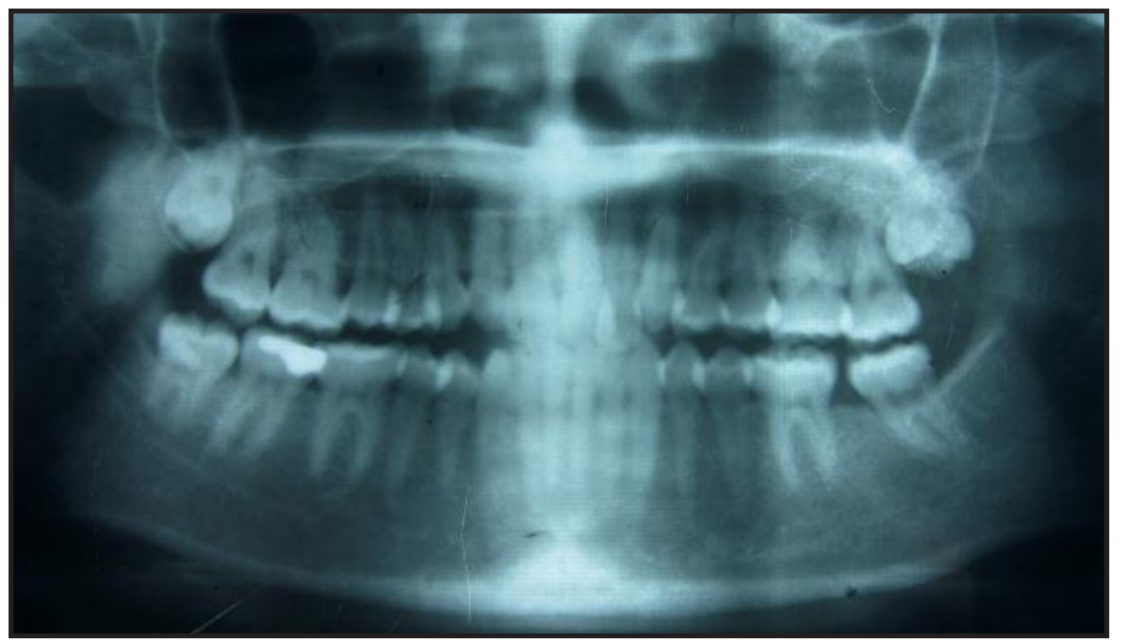

Gambar 3. Panoramik sebelum perawatan

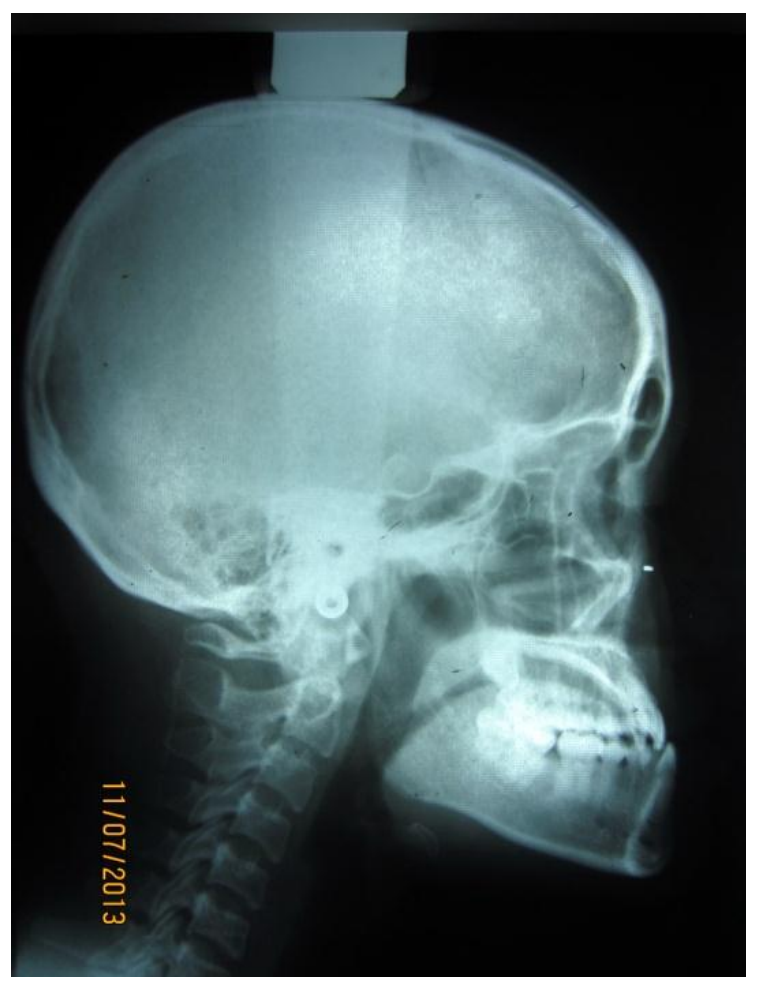

Gambar 4. Sefalometri sebelum perawatan

Analisis ruang berdasarkan determinasi lengkung dan set up model Kesling dengan lengkung ideal dilakukan protraksi gigi anterior rahang atas $5 \mathrm{~mm}$ menunjukkan kekurangan ruang pada rahang atas kanan sebesar 2,44 mm, kiri 2,57 mm, kekurangan ruang pada rahang bawah kanan sebesar
6,74 mm dan kiri 6,54 mm. Kebutuhan ruang pada rahang atas didapat dari pencabutan gigi 15 dan 25 . Kebutuhan ruang pada rahang bawah didapatkan dari pencabutan gigi 34 dan 44. Kelebihan ruang pada rahang atas digunakan untuk memperbaiki hubungan gigi molar. 
Perawatan tahap I kasus ini dilakukan dengan pemasangan braket dan pemasangan Australian wire diameter 0,016" yang dilengkapi dengan vertical loop di antara gigi 13-12 dan 22-23. Circle hook dibuat pada distal braket gigi kaninus untuk keperluan protraksi gigi anterior rahang atas serta stopper pada mesial braket gigi molar pertama. Vertical loop pada rahang bawah terletak di antara gigi 32-33, 31-32 dan 43-42. Gigi insisivus sentral digeser terlebih dahulu untuk memberi ruang gigi insisivus lateral kiri rahang atas. Perawatan dilakukan sampai tercapai hubungan gigi-gigi anterior posisi klas I. Pada kasus ini digunakan elastik intermaksilar klas III ukuran 5/16" 2 oz dan anchor bend sebesar $15^{\circ}$.

Tahap II dilakukan setelah tahap I selesai. Kawat yang digunakan pada tahap II adalah plain archwire diameter 0,016" dengan circle hook tepat pada mesial braket gigi kaninus. Penutupan ruang bekas pencabutan dilakukan dengan ligasi gigi anterior rahang atas sebagai reverse anchorage. Gigi posterior digerakkan ke mesial sampai terjadi hubungan gigi molar yang baik. Elastik intramaksilar yang digunakan ukuran $1 / 4$ " 3 oz. Tahap III dilakukan setelah tahap II selesai. Kawat yang digunakan pada tahap III adalah plain archwire diameter 0,018" dengan circle hook tepat pada mesial braket gigi kaninus. Tahap III merupakan tahap finishing dan root paralleling.

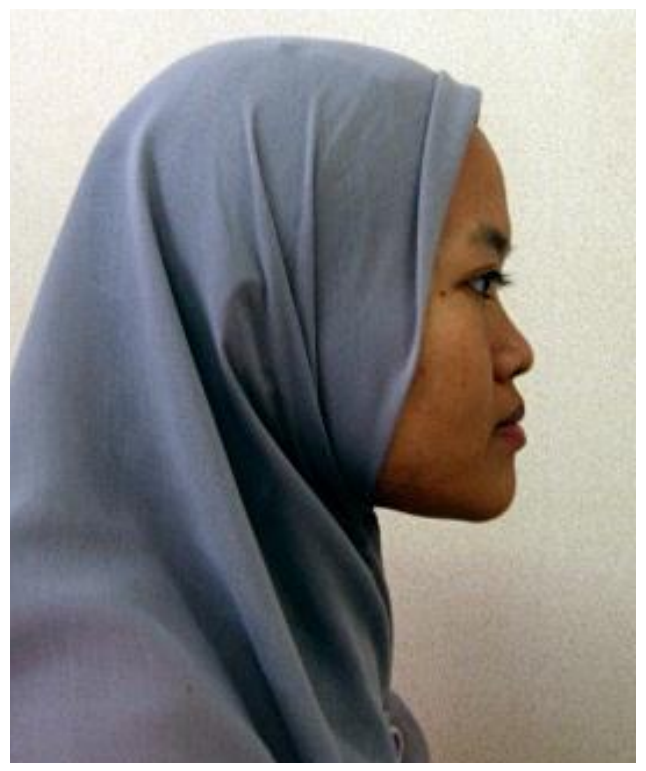

Gambar 5. Profil samping selama 2 tahun 4 bulan perawatan

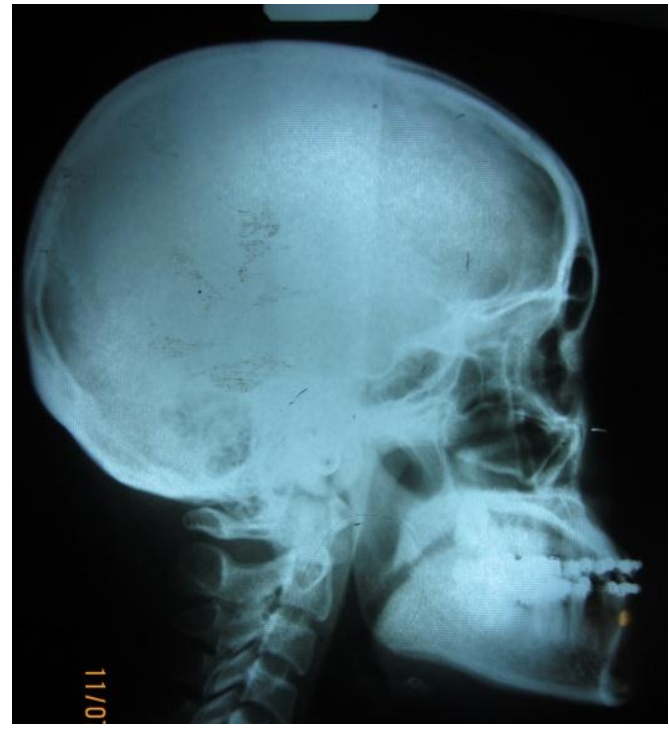

Gambar 6. Sefalometri selama 2 tahun 4 bulan perawatan

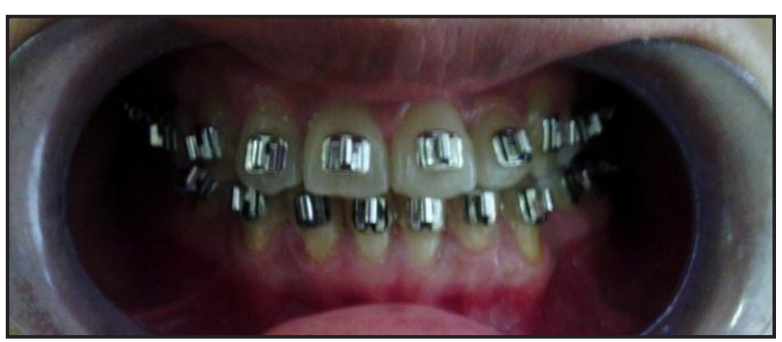

Gambar 8. Tampak depan selama 2 tahun 4 bulan perawatan

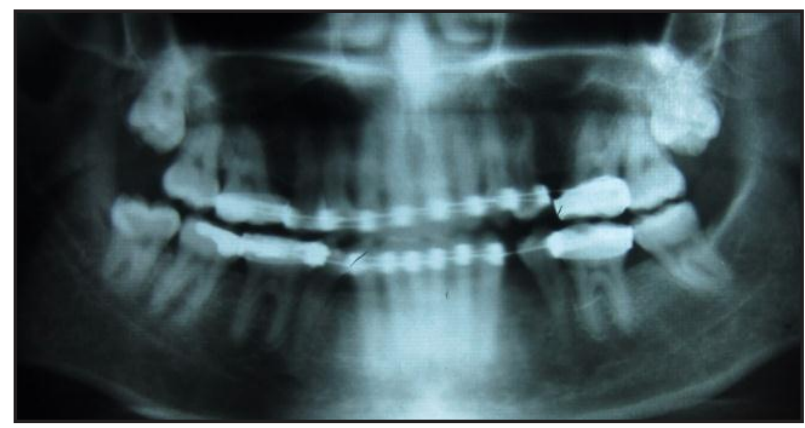

Gambar 9. Panoramik selama 2 tahun 4 bulan perawatan

Perawatan telah dilakukan selama 2 tahun 4 bulan, malposisi dan malrelasi gigi individual terkoreksi. Overjet bertambah menjadi $3 \mathrm{~mm}$ sedangkan overbite $3 \mathrm{~mm}$. (gambar 6). Hasil perawatan yang telah dicapai, terlihat melalui sefalogram, FIS menjadi $129^{\circ}$, IMPA $71^{\circ}$, dan sudut interinsisal $144^{\circ}$ (Tabel 1 ) 
Tabel 1. Pengukuran sefalometri sebelum dan sesudah perawatan selama 2 tahun 4 bulan.

\begin{tabular}{|c|c|c|c|c|}
\hline Pengukuran & Nilai normal & $\begin{array}{l}\text { Sebelum } \\
\text { perawatan }\end{array}$ & $\begin{array}{c}\text { Selama } \\
\text { perawatan }\end{array}$ & Perubahan \\
\hline Facial angle & $82^{\circ}-95^{\circ}$ & $98^{\circ}$ & $90,5^{\circ}$ & $7,5^{\circ}$ \\
\hline Angle of convexity & $8,5^{\circ}-10^{\circ}$ & $-2^{\circ}$ & $2,5^{\circ}$ & $4,5^{\circ}$ \\
\hline Bidang A-B & $0-\left(-9^{\circ}\right)$ & $1^{\circ}$ & 0 & $1^{\circ}$ \\
\hline FMPA & $17^{\circ}-28^{\circ}$ & $17^{\circ}$ & $19,5^{\circ}$ & $2,5^{\circ}$ \\
\hline Y-Axis & $53^{\circ}-66^{\circ}$ & $53^{\circ}$ & $53,5^{\circ}$ & $0,5^{\circ}$ \\
\hline SNA & $82^{\circ}$ & $87^{\circ}$ & $90^{\circ}$ & $3^{\circ}$ \\
\hline SNB & $80^{\circ}$ & $91^{\circ}$ & $89^{\circ}$ & $2^{\circ}$ \\
\hline ANB & $2^{\circ}$ & $-4^{\circ}$ & $1^{\circ}$ & $5^{\circ}$ \\
\hline Bidang Mandibula -SN & $32^{\circ}$ & 22,5 & $22^{\circ}$ & $0,5^{\circ}$ \\
\hline Inter 'I dan 1 & $130^{\circ}$ & 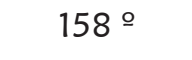 & $144^{\circ}$ & $14^{\circ}$ \\
\hline Sudut I- NA & $22^{\circ}$ & $5^{\circ}$ & $33^{\circ}$ & $28^{\circ}$ \\
\hline I-NA (mm) & $4 \mathrm{~mm}$ & $-5 \mathrm{~mm}$ & $4 \mathrm{~mm}$ & $9 \mathrm{~mm}$ \\
\hline IMPA & $81.5^{\circ}-97^{\circ}$ & 81,5 & $71^{\circ}$ & $10,5^{\circ}$ \\
\hline Sudut I-NB & $25^{\circ}$ & $18,5^{\circ}$ & $5,5^{\circ}$ & $13^{\circ}$ \\
\hline $\mathrm{I}-\mathrm{NB}(\mathrm{mm})$ & $4 \mathrm{~mm}$ & $2,5 \mathrm{~mm}$ & 0 & $2,5 \mathrm{~mm}$ \\
\hline Bidang oklusal -SN & $14^{\circ}$ & $11^{\circ}$ & $7^{\circ}$ & $4^{\circ}$ \\
\hline Occl PI-FHP & $1,5^{\circ}-14,3^{\circ}$ & $4^{\circ}$ & $6^{\circ}$ & $2^{\circ}$ \\
\hline FIS & $105^{\circ}-115^{\circ}$ & $100^{\circ}$ & $129^{\circ}$ & $29^{\circ}$ \\
\hline Overbite & $2-4 \mathrm{~mm}$ & $3,1 \mathrm{~mm}$ & 3 & $0,1 \mathrm{~mm}$ \\
\hline Overjet & $2-4 \mathrm{~mm}$ & 3 & 3 & 0 \\
\hline
\end{tabular}

\section{PEMBAHASAN}

Maloklusi kasus ini disebabkan oleh faktor keturunan, diketahui dari hasil anamnesis adik laki-laki pasien yang memiliki dagu maju mirip dengan pasien. ${ }^{4,10}$ Perawatan yang dilakukan adalah perawatan kamuflase. Perawatan kamuflase adalah perawatan maloklusi dengan kasus skeletal tetapi perawatan hanya dilakukan pada perawatan dental tanpa melakukan pembedahan. Kombinasi stop di mesial gigi Molar pertama, circle hook dan veritkal loop, menghasilkan protraksi yang diharapkan. Reverse overjet mengakibatkan penampilan yang tidak estetis, kesulitan dalam berbicara maupun mengunyah makanan. Keadaan tersebut mengakibatkan pasien merasa sangat tidak nyaman. Hasil pemeriksaan klinis terhadap keadaan pasien didapatkan dagu pasien saat mengayun ke belakang tidak dapat mencapai posisi normal maupun posisi edge to edge, sehingga disimpulkan keadaan maloklusi pasien merupakan maloklusi klas III true skeletal. Kasus ini memerlukan pembedahan, namun akibat keadaan sosial ekonomi pasien yang tidak memungkinkan, maka perawatan maloklusi yang dilakukan merupakan perawatan kamuflase. Hasil perawatan diharapkan mendekati normal. ${ }^{11,12}$ 
Koreksi reverse overjet dilakukan dengan alat cekat teknik Begg yang terdiri dari tiga tahap. Tahap pertama adalah koreksi reverse overjet, crossbite, dan edge to edge. Kawat yang digunakan diameter 0,016" untuk ekspansi anteroposterior dengan stopper di mesial tube molar. Elastik yang digunakan adalah elastik klas III ukuran 5/16" 2 oz. Tahap kedua penutupan ruang bekas pencabutan, kawat yang digunakan adalah plain archwire diameter 0,018" dengan circle hook tepat pada mesial braket gigi kaninus. Anchor bend yang digunakan sebesar $15^{\circ}$. Mesialisasi gigi posterior dilakukan dengan cara ligasi gigi anterior sebagai reverse anchorage untuk menarik gigi posterior ke depan satu per satu sehingga terjadi hubungan gigi molar yang baik. Elastik intramaksilar yang digunakan ukuran 1/4" $4 \mathrm{oz}$. Tahap ketiga adalah root paralleling. Kawat yang digunakan plain archwire ukuran 0,020" dengan circle hook tepat di mesial braket gigi kaninus serta anchor bend sebesar $15^{\circ}$ untuk stabilisasi. Lingual root torque dan palatal root torque digunakan untuk menghasilkan overjet sesuai rencana perawatan sebesar $2 \mathrm{~mm}$. Cinch back digunakan untuk mempertahankan lengkung gigi. Elastik intemaksiler yang digunakan pada perawatan tahap III adalah elastik intermaksiler klas III ukuran 5/16" 2 oz. ${ }^{8,9}$

Hasil foto dan sefalogram dua tahun perawatan menunjukkan perubahan pada overbite dan overjet (gambar 2, 6, dan 8). Keadaan reverse overjet sebelum perawatan berubah menjadi normal, meskipun belum sesuai dengan rencana perawatan. Overjet yang direncanakan sebesar $2 \mathrm{~mm}$ diharapkan akan tercapai pada tahap III. Hasil perawatan didapatkan overbite $3 \mathrm{~mm}$ serta overjet $3 \mathrm{~mm}$. Evaluasi sefalogram menunjukkan perubahan pada FIS menjadi $129^{\circ}$, IMPA $71^{\circ}$, dan sudut interinsisal $144^{\circ}$. (Tabel 1). Perubahan relasi anterior rahang atas dan rahang bawah terjadi karena perubahan inklinasi insisivus atas dan bawah akibat protraksi gigi-gigi anterior. ${ }^{13}$

Kesulitan perawatan kasus ini adalah pada koreksi reverse overjet terutama akibat pengaruh skeletal dan perawatan dilakukan tanpa pembedahan, sehingga hasil yang didapatkan merupakan perawatan kamuflase di mana relasi overjet terlihat seperti normal. Prognosis perawatan maloklusi klas III true skeletal cenderung kurang baik. Sejauh ini kooperasi pasien sangat membantu kelancaran perawatan..$^{2,11}$

\section{KESIMPULAN}

Perawatan ortodontik kamuflase pada maloklusi klas III dengan alat ortodontik cekat teknik Begg menunjukkan hasil yang cukup baik, dengan terkoreksinya reverse overjet, crossbite, dan edge to edge. Prognosa kasus ini kurang menguntungkan, namun demikian kooperasi pasien sangat baik sehingga hasil perawatan cukup memuaskan

\section{DAFTAR PUSTAKA}

1. Fletcher GGT. The Begg Appliance and Technique. Briston: John Wright \& Sons (print) Ltd; 1981. 135-44.

2. Alhaija ESJ. Attractiveness rating of anterior open bites and reverse overjets using the aesthetic component of the index of orthodontics treatment need. European Journal of Orthodontics. 2005; 27: 134-139.

3. Beckmann SH, Kuitert RB, Prahl-Andersen, Segner $D$, Tuinzing DB. Alveolar and skeletal dimensions associated with overbite. Am J Orthod Dentofac Orthop. 1998; 113: 443-52.

4. Bhalajhi Sl. Orthodontics: The art and science, $3^{\text {rd }}$ ed., New Delhi: Arya (Medi) Publishing House; 2004. H. 407-414.

5. Stellzig-Eisenhauer A, Lux CJ, Schuster G. Treatment decision in adult patients with class iii malocclusion : orthodontic therapy or orthognatic surgery?. Am J Orthod Dentofac Orthop. 2002; 122: 27-38.

6. Johnston C, Burden D, Kennedy D, Harradine $\mathrm{N}$, Stevenson $\mathrm{M}$ : Class III surgical treatment : a cephalometric study. Am J Orthod Dentofac Orthop. 2006; 130: 300-9.

7. Parkhouse RC. Differential tooth movement in "uphill cases". Am J Orthod Dentofac Orthop. 1992; 101: 491-500

8. Begg PR, Kesling PC. Begg orthodontic theory and technique. Ed. 2. Philadelphia: W.B. Saunders Co; 1977. H. 88-95. 
9. Reddy P, Kharbanda OP, Duggal R, Parkash $\mathrm{H}$. Skeletal and dental changes with nonextraction begg mechanotherapy in patients with class II division I malocclusion. Am J Orthod Dentofac Orthop. 2000; $118: 641-8$.

10. Graber TM, Vanarsdall. Orthodontic current principles and techniques. $5^{\text {th }}$ ed. Philadelphia: WB Saunders Company; 2012. H. 59-98.
11. Ackerman JL, Proffit WR. Soft tissue limitations in orthodontics : treatment planning guidelines, Angle Orthod. 1997; 67(5): 327-336.

12. Staley RN, Reske NT. Essentials of orthodontics. Blackwell Publishing; 2011. H. 3-74.

13. Jacobson A. Radiographic cephalometri. Chicago: Quintessence Publishing Co; 1995. H. 53-95. 